\title{
Nutritional Composition and Polyphenolic Content of Edible Peumus boldus Mol. Fruits.
}

\author{
Patricia Velásquez1, María Ignacia Sandoval², Ady Giordano ${ }^{3}$, Miguel Gómez², \\ Gloria Montenegro ${ }^{1}$ \\ ${ }^{1}$ Pontificia Universidad Católica de Chile, Facultad de Ingeniería, Departamento de Química e Ingeniería \\ en Bioprocesos. Avenida Vicuña Mackenna 4860, Macul, Santiago, Chile. \\ ${ }^{2}$ Pontificia Universidad Católica de Chile , Facultad de Agronomía e Ingeniería Forestal, Departamento de \\ Ciencias Vegetales. Avenida Vicuña Mackenna 4860, Macul, Santiago, Chile. \\ ${ }^{3}$ Pontificia Universidad Católica de Chile, Facultad de Química, Departamente de Química Inorgánica. \\ Avenida Vicuña Mackenna 4860, Macul, Santiago, Chile.
}

\begin{abstract}
P. Velásquez, M.I. Sandoval, A. Giordano, M. Gómez, and G. Montenegro. 2017. Nutritional Composition and Polyphenolic Content of Edible Peumus boldus Mol. Fruits. Cien. Inv. Agr. 44(1): 64-74. Peumus boldus is an endemic Chilean tree whose edible fruit lack a history of scientific research. The aim of this study was to determine its nutritional composition (moisture, ash, crude fiber, proteins, carbohydrates and lipids) and polyphenolic content (total phenolic content, HPLC-DAD, HPLC-MS/MS analysis) at different stages of development. The results show that the fruit decreased in ash, crude fiber and total phenolic content throughout its development, while its carbohydrate and protein content increased. An increase in phenolic molecules such as catechin and epicatechin was also observed. This is the first report on the nutritional composition and phenolic content of Peumus boldus Mol. fruits.
\end{abstract}

Keywords: Ash, crude fiber, Kjeldahl, Goldfish, phenol-sulfuric method, total phenolic content.

\section{Introduction}

Historically, there has been interest in natural products derived from plants and other living organisms because they provide a great diversity of chemical compounds of useful character (Ertl and Schuffenhauer, 2008). These natural

Received September 26, 2016. Accepted January 27, 2017. Corresponding author: gmonten@uc.cl substances have been used in human and animal food industries for their high nutritional value and low toxicity. In addition, they are used in the pharmaceutical industry for the development of drugs and vaccines, in the agrochemical industry for the production of fertilizers and pesticides, and in the cosmetics industry (Krause and Tobin, 2013). Facing the current increase of chronic and deadly diseases caused by a simplified diet with fat and carbohydrates, countries around the world have started massive campaigns to promote healthier 
food intake. The Food and Agriculture Organization is actively promoting the conservation and sustainable use of biodiversity for nutrition and food security. In this sense, biodiversity contributes to improving diets since the nutritional value differs greatly between species, varieties and races, which favors a balanced and varied diet.

Chile is a country with food-source potential due to its biodiversity and floral endemism (CONAMA, 2008). Studies identifying the chemical properties of certain Chilean species have been increasing, especially since native fruits have shown high antioxidant capacity compared with exotic fruits such as blueberry and raspberry (Fredes, 2009). The Forestry Institute of Chile generated a ranking of species of the native forest that have potential in the social, economic, environmental and technological sectors, with the aim of promoting and diversifying their research (INFOR, 2014). The products obtained from these species, called Non-Timber Forest Products (NTFP), have experienced a considerable increase in exports. In 2009, the value of exports was US \$ FOB 62 million (INFOR, 2010), while the last report delivered by INFOR 2014 yielded a value of US \$ FOB 67.8 million. The species that lead INFOR's ranking are Aristotelia chilensis (maqui), Quillaja saponaria (quillay), Gevuina hazel (hazel) and Peumus boldus (boldo).

The products obtained from Peumus boldus are essential oil, bark, encapsulated powder, tea leaves and dried leaves. Scientific studies concerning Peumus boldus have focused mainly on its leaves, which show high antioxidant activity due to their high flavonoid concentrations (Fale et al., 2012). Also, essential oil from boldo leaves has shown fungistatic activity against Pythium and Rhizoctonia solani irregulare (Bittner et al., 2009). However, there is no information related to the properties of boldo fruits.

The present study seeks to identify the potential of Peumus boldus fruits, an edible fruit (Montenegro, 2002) that has lacked scientific interest until now. The aim of this study was to determine the nutritional composition in three stages of development (i.e., moisture, ash, crude fiber, total protein, total carbohydrates and total lipids) and its polyphenolic content.

\section{Materials and Methods}

\section{Plant material}

Boldo fruits were collected from wild specimens in the central area of Chile ( $33^{\circ} 36^{~ ' S}, 71^{\circ} 02^{\prime}$ ' W), which presents a Mediterranean type-climate (long dry season and rainy winter, with average annual temperature of $13.9^{\circ} \mathrm{C}$ and $369.5 \mathrm{~mm}$ average annual water) (Integrated Land Information System of Chilean Congress Library, SIIT).

The collection of the fruits was performed on three dates, $30 \mathrm{~d}$ apart, collectin samples from the female examples (dioecious species), discarding those with external damage. The criterion used to collect the fruits was the time of fruiting or fruit maturation period (Botti and Cabello, 1990), and in order to homogenize the samples, fruits that showed similar color and size were chosen. The collection was performed according to the method of non-probability sampling called convenience sampling (Tacón, 2004).

The first collection, designated State I, was at the first stage of development of the fruit subject to analysis. The second collection was designated State II, and the third sample was designated State III.

Once harvested, the fruits were transferred to laboratory in plastic bags and kept in cold storage at $5{ }^{\circ} \mathrm{C}$.

\section{Morphometric characterization}

Boldo flowers are apocarpic and produce several fruits per flower, and they were grouped accordingly (i.e., groups of one fruit per flower, two 
fruit per flower formed, etc.). Ten fruits, with four replications in each group, were measured (diameter and length) and weighed in order to obtain an average size and weight and to determine differences depending on whether the fruits were solitary or grouped.

\section{Histological study}

Ten fruits chosen randomly in state I were reserved for histological study: the fruits were dehydrated using several concentrations of tertiary butyl alcohol and then included in paraffin in an oven at $58{ }^{\circ} \mathrm{C}$ and transected at a thickness of $15 \mu \mathrm{m}$ using a hand microtome. The cross sections were stained using differential safranin and green dyes. Finally, the sections were mounted and sealed with chemical glue. The preparations were observed by light microscope using a magnification of 40, 100 and $400 \mathrm{x}$.

\section{Nutritional characterization}

The fruits were frozen at $-20{ }^{\circ} \mathrm{C}$ (MIMET, VV16BTF) and lyophilized for $24 \mathrm{~h}$ (Labconco, Freezone1, Benchtop Freeze Dry) for nutritional characterization and determination of total phenolic content.

Moisture content, ash, crude fiber and total phenolic content for states I, II and III were measured in order to observe some variation according to the state of development of the fruit. The content of total proteins, total lipids and total carbohydrates was determined only for state III, the most advanced and suitable for consumption.

\section{Moisture content}

Moisture content determination was performed using the stove drying method (Nielsen, 2003), which consisted of drying $30 \mathrm{~g}$ of fruit (peel, flesh and seed) in an oven at $100{ }^{\circ} \mathrm{C}$ for two hours. The moisture content was measured by weight difference and expressed as grams of water in $100 \mathrm{~g}$ of sample.

\section{Ash content}

The total ash drying method was used (Kirk et $a l ., 1996)$. Each sample (30 g only flesh and peel) was burned in a Bunsen burner and then in a muffle furnace at $550{ }^{\circ} \mathrm{C}$ for two hours. The ash content was measured by weight difference and expressed as grams of ash in $100 \mathrm{~g}$ of sample.

\section{Crude fiber content}

Total content of crude fiber was determined by oxidation and acid hydrolysis (Schmidt Hebbel et al., 2001). Acetic acid, trichloroacetic acid and nitric acid was added to the sample (30 g only flesh and peel) and heated at $90{ }^{\circ} \mathrm{C}$ for $30 \mathrm{~min}$. The fiber was then filtered, washed with distilled water and dried. The crude fiber content was measured by weight difference and expressed as grams of crude fiber in $100 \mathrm{~g}$ of sample.

\section{Carbohydrate content}

Carbohydrate determination was performed by a spectrophotometric method with phenol-sulfuric acid (Dubois et al., 1956; Khoddami et al., 2013). Methanolic extracts of the fruits were deproteinized with demineralized water, zinc sulfate and sodium hydroxide. Then, a solution of phenol and concentrated sulfuric acid was added. Determination of total sugars was performed at 490 $\mathrm{nm}$, and the results were expressed as equivalent milligrams of glucose (mg EG).

\section{Total lipid content}

The determination was made by using the Goldfish method (Pomeranz and Meloan, 2000). A sample of $30 \mathrm{~g}$ (peel, flesh and seed) was introduced into 
a cellulose cartridge and then extracted with ethyl ether. The results were calculated by weight difference and expressed as grams of fat in $100 \mathrm{~g}$ of sample (Gil, 2010).

\section{Total protein content}

Total protein content was assessed by the Kjeldahl method (AOAC, 2001). Briefly: each sample was introduced into a Kjeldahl tube containing copper sulfate pentahydrate, sodium sulfate and concentrated sulfuric acid and heated for $2 \mathrm{~h}$. The tubes were placed in a semi-automatic Kjeldahl distiller, receiving the vapors of boric acid with methyl red indicator. Hydrochloric acid was used for titration. Protein content was expressed as grams of protein in $100 \mathrm{~g}$ of sample.

\section{Total phenolic content}

Samples of $30 \mathrm{~g}$ were immersed in $90 \mathrm{~mL}$ of methanol, sonicated (BRANSON 2200) for one hour, and centrifuged (MSE Super minor) for 15 $\mathrm{min}$ at $3000 \mathrm{rpm}$. The supernatant was vacuum evaporated (BÜCHI Switzerland), and the content was diluted in distilled water. The extract was filtered with a $0.45 \mu \mathrm{m}$ filter to remove possible bacterial contamination (Khoddami et al., 2013).

Determination of total phenols by the FolinCiocalteu method (Beretta et al., 1996) was performed for the three fruit stages and expressed as milligrams of Gallic acid equivalent in a $\mathrm{kg}$ fresh weight (mg EAG / kg FW).

The identification of flavonoids and phenolic acids was performed by high-performance liquid chromatography with a diode array detector based on reported methods (Pyrzynska and Biesaga, 2009; Montenegro et al., 2009; Yao et al., 2003) and confirmed by HPLC-MS/MS.

A LaChrom Elite L-2130 binary pump coupled to a DAD L-2440 detector with a $20 \mu \mathrm{L}$ sample loop injector was used. A LiChroCART RP-18 column $(5 \mu \mathrm{m} \times 4.6 \times 150 \mathrm{~mm})$ with a guard column of the same material was used in an L-2300 oven at 35 ${ }^{\circ} \mathrm{C}$. Separation was performed with a mobile phase of aqueous formic acid 5\% (v/v) (A) and methanol (B) at constant solvent flow of $1 \mathrm{~mL} \mathrm{~min}^{-1}$ with a concentration gradient of $30-35 \%$ A (0-12 min) and $35 \% \mathrm{~A}$ (12-105 min). Chromatograms were monitored at 290 and $340 \mathrm{~nm}$. To determine the concentration of compounds, a calibration curve was made with high purity standards.

An ABSciex triple Quad 4500 mass spectrometer equipped with an electrospray (TurboV) interface coupled to an Eksigent Ekspert Ultra LC100 with an Ekspert Ultra LC100-XL autosampler system (AB/Sciex Concord, Ontario, Canada) was used in order to confirm the HPLC-DAD analysis. The chromatographic separation was carried out at $50{ }^{\circ} \mathrm{C}$ on a LiChrospher $100 \mathrm{RP}-18$ endcapped column $(125 \mathrm{~mm} \times 4 \mathrm{~mm}$ id, $5 \mu \mathrm{m})$ (Merck, Darmstadt, Germany) using gradient elution with $0.1 \%$ formic acid in water (A) and methanol (B) as mobile phase. The gradient was programmed as follows: $0-1 \mathrm{~min}, 15 \% \mathrm{~B}$; $1-17 \mathrm{~min}, 15-100 \% \mathrm{~B}$; 17-21 min 100-100\% B; $21-22$ min, $100-15 \%$ B; $22-25 \mathrm{~min}, 15-15 \% \mathrm{~B}$. The injection volume was $10 \mu \mathrm{L}$ and the flow rate was kept at $0.5 \mathrm{~mL} \mathrm{~min}^{-1}$.

\section{Statistical analysis}

Descriptive statistics (mean and standard deviation), ANOVA and Tukey tests (HSD) were performed using Statgraphics Centurion XV software with a level of significance of $\mathrm{p}<0.05$. The data presented are representative of those obtained in at least three independent experiments done in triplicate.

\section{Results and discussion}

\section{Morphometric characterization}

Boldo has white-yellow unisexual flowers and an inflorescence in clusters with 5-12 flowers, axil- 
lary or terminal (Rodríguez, 1983). The fruits of Monimiaceae trees such as boldo can be classified into 2 types (Romanov, 2007): apocarpic drupes or apocarpic berries. In the case of a drupe, endocarp differentiation distinguishes 4 different types, according to greater or lesser degrees of development.

Peumus boldus develops drupes, belonging to Monimia type, in which the endocarp is well developed forming $3 / 4$ of the thickness of the pericarp. In other drupes (Hortonia, Mollinedia and Hedycarya), the endocarp has progressively reduced thickness. Rodriguez et al. (1983) describes the fruit as "a drupe 6-8 mm long, shortly stipitate on the disc and assembled in number of $2-5$, rarely solitary with a seed abundant in endosperm".

In boldo samples (Figure 1), the development of one, two, three, four or five fruits per flower was observed (up to 7 can develop according to Rodriguez et al., (1983)) in the three states of boldo fruit because boldo presents an apocarpous gynoecium, so the flowers have the ability to develop more than one fruit at a time.
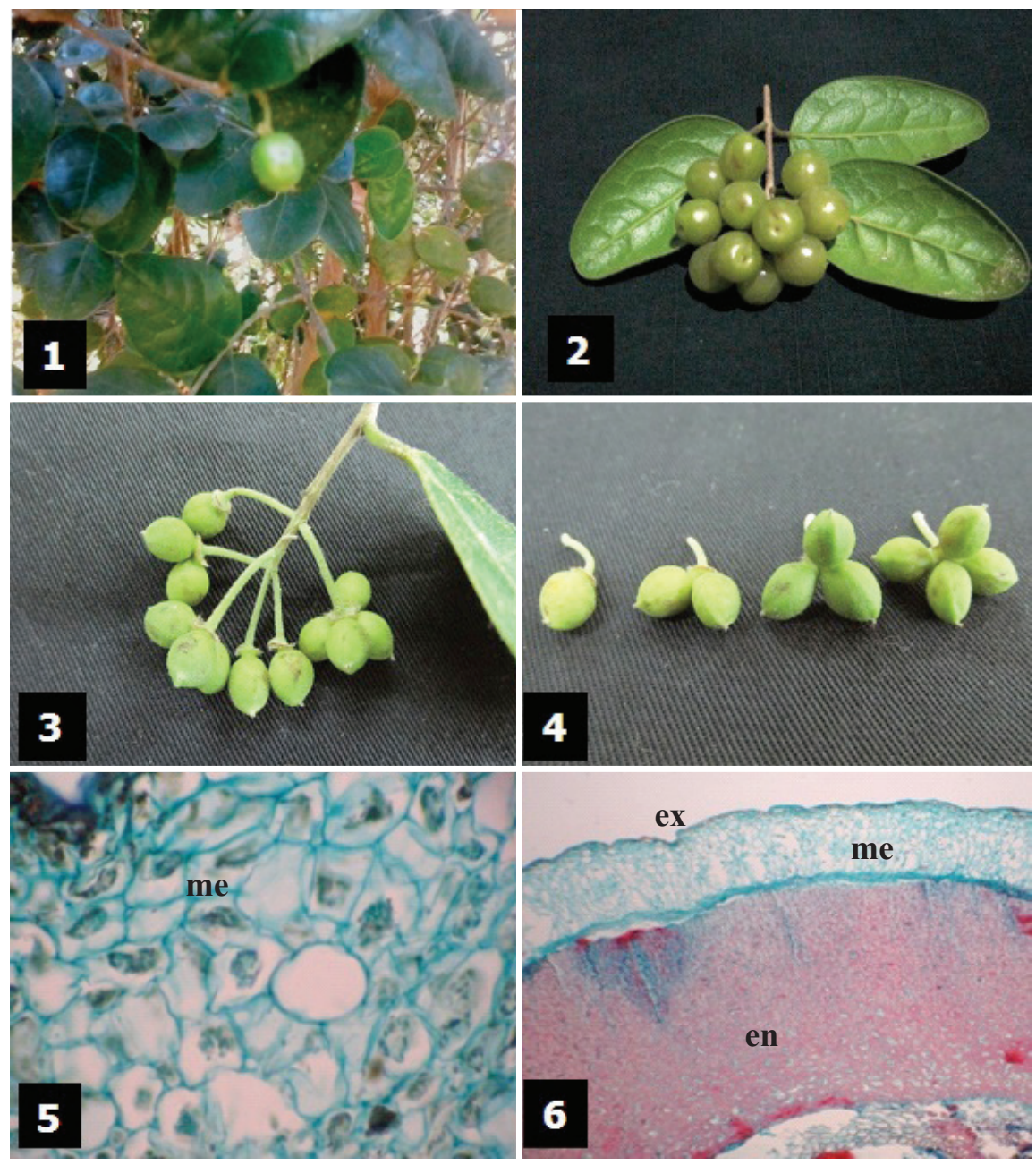

Figure 1. Boldo fruits at different stages of development: 1) Immature fruit on a boldo tree; 2) Mature boldo fruits; 3-4) Number of fruits per flower; 5) Histological sections of boldo fruit: Oil cavity in mesocarp (me) 400x; 6) Cross section through the three constituent layers: exocarp (ex), mesocarp (me) and endocarp (en) 40x. 
The highest frequency of fruits per flower among the samples collected corresponds to 1 fruit/flower in the three stages of development, with $48.7 \pm$ $2.5 \%$ frequency, followed by 2 fruit/flower at 33.7 $\pm 5.0 \%$ and 3 fruit/flower at $11.0 \pm 5.3 \%$. Four and five fruits per flower had a frequency lower than $4.0 \pm 2.0 \%$. This result differs from that reported by Rodriguez et al. (1983), who mentioned that the fruits rarely develop alone.

The drupes with larger dimension were those that came from samples with five fruits per flower. It was observed that fruit dimensions showed a significant difference at state III: the fruits were between 5 and $9 \%$ larger than the fruits from states I and II.

The weight of fruits in the first state had an average of $196.0 \pm 11.4 \mathrm{mg}$, while an average of 244.0 $\pm 11.4 \mathrm{mg}$ at second state and $292.5 \pm 15.0 \mathrm{mg}$ at third state was observed. In addition, the wet weight of fruits gradually increased as the number of fruits per flower increased in the three stages of development. It had been expected that the fruits alone (i.e., only one fruit) from each flower would be larger than those presented in groups.

In Figure 1, histological study showed that boldo fruit presents a well differentiated epicarp, mesocarp and endocarp. Epicarp is formed by a layer of cells with tannins in their cytoplasm and on its surface are stomata and stellate trichomes. The mesocarp comprises parenchymal cells and abundant cavities with essential oils (oleiferous cavities). The endocarp (representing up to $4 / 5$ the thickness of the pericarp, according to Romanov et al., (2007)) is lignified and consists of several layers with abundant sclereids.

\section{Nutritional characterization}

The moisture content of edible fruit is a parameter that allows a classification of the fruit. Fleshy fruits show more than $50 \%$ water, as in the case of lemon and watermelon, while nuts contain less than $50 \%$ water, such as almonds and walnuts (corresponding to the seed of the fruit) (Gil, 2010). In addition, water content varies during the development and maturation of the fruit.

The moisture content of the boldo fruits showed a decrease between states I and II, from 56.5\% to $47.6 \%$, and an increase up to $53.6 \%$ at state III (Table 1). These results are related to the dynamics of fruit ripening. It can be assumed that boldo fruit has a double sigmoid growth curve since it is characteristic of the pit or stone fruits, such as drupes (Coombe, 1976). A double sigmoid growth curve is characterized by two periods of growth. The first period of formation of the fruit and seed is characterized by intense cell division, which determines the total number of cells that the fruit has. Furthermore, a cell thickening process occurs, in which there is a large accumulation of water and hydrocarbon substances, so that the fruit weight and volume increases to almost normal size (Gil-Albert Velarde, 2006). A transition period occurs when the fleshy tissue will grow slowly, while the seed will continue its rapid development (Coombe, 1976), increasing the dry matter content. The second phase of growth is correlated with changes in metabolism of the plant, such as loss of chlorophyll, fruit softening, development of aroma and flavor, and increased water content due to respiration (Kramer and Kozlowski, 1976). Towards the end of the second period of growth, the fruit increases its dry matter content (reduced water content), a process that is explained by the arrival of carbohydrates, nitrogen compounds and minerals from other plant organs (Arena and Curvetto, 2008).

The moisture content at state I could be explained by cell thickening due to a great accumulation of water. The decrease of water in state II of growth can be attributed to the rapid growth of endocarp and the high proportion it occupies in relation to the total size of the fruit. The increased water content in state III could be explained by an increase in respiration rate of the fruit due to the second growth phase. It can be inferred that 
Table 1. Nutritional values of boldo fruit in three development stages.

\begin{tabular}{lccc}
\hline $\left.\begin{array}{l}\text { Content } \\
(\mathrm{g} \mathrm{100g} \text { fresh fruit }\end{array}{ }^{-1}\right) \dagger$ & State I & State II & State III \\
\hline Moisture & $56.50 \pm 6.31$ & $47.57 \pm 14.61$ & $53.57 \pm 10.54$ \\
Ash & $4.58 \pm 0.14$ & $4.77 \pm 0.03$ & $3.89 \pm 0.09$ \\
Crude fiber & $8.54 \pm 3.07$ & $4.90 \pm 2.90$ & $0.45 \pm 0.22$ \\
\hline
\end{tabular}

$\dagger$ Average \pm standard deviation; $\mathrm{n}=3$

state III of boldo fruits corresponds to a prior state of total maturity because a decrease in the total water content exists in the last stage.

The results for ash content in boldo are similar to those reported in the literature, as it does not exceed $5 \%$ of the sample and represents the total content of minerals in fresh foods (Nielsen, 2003). The samples showed variation in the ash content during ripening: while among states I and II ash content was similar (4.6 and $4.8 \%$, respectively), it decreased significantly to $3.9 \%$ in state III (Table 1). The variations found in the mineral content of the boldo fruits may be related to the age of the fruit since mineral elements enter into the fruits at different rates, depending on the state of development in which the fruit is. For example, calcium is absorbed only in the first stage of fruit development, while potassium is constantly absorbed (Valvi and Rathod, 2011). While there is no detailed mineral content data for boldo fruit, variations in ash content could be explained by the flow of minerals that occurs during maturation. Similar decreases in ash content in blackberry fruit have been reported in the literature (AcostaMontoya et al., 2010), and higher decreases were found in the maturation process of açaí (Euterpe oleraceae Mart.) (Gordon et al., 2012).

During the development of boldo fruits, a progressive decrease in crude fiber content was observed. State I showed $8.54 \mathrm{~g}, 4.9 \mathrm{~g}$ in state II, and $0.45 \mathrm{~g}$ per $100 \mathrm{~g}$ serving in state III (Table 1). The concept of crude fiber has varied over the years, and it depends on the approach from which it is being analyzed because fiber is a complex compound and its determination method varies with the usage. The definition currently accepted is delivered by Trowell: "dietary fiber consists of cellular debris of plants that are resistant to hydrolysis (digestion) for human digestive enzymes, and has components such as hemicellulose, cellulose, lignin, oligosaccharides, pectins and waxes (Rodríguez et al., 2006)". The method used for the determination of crude fiber, called oxidation and acid hydrolysis, only solubilizes the lignin content, so this analysis is based on the variation of lignin content during fruit development. The decrease in crude fiber content of boldo fruits could be due to a progressive decrease in the lignin content of the mesocarp, resulting in loss of firmness when the fruit reaches maturity since a similar process has been reported for the fruit of the medlar (Eriobotrya japonica Lindl.) (Cai et al., 2006). In contrast, a decrease in fruit firmness of pepper (Capsicum annuum) correlates with a decrease in the lignin content thereof (Estrada et al., 2000).

Only samples from stage III were analyzed for carbohydrate content since sugars such as sucrose, glucose and fructose are in higher proportions after ripening, reaching up to $16 \%$ (Gil, 2010).

The total carbohydrate content of the boldo fruits was $1.1 \%$ (Figure 2). This value is similar to the sugar content reported for low-carb fruits such as avocado and watermelon, with 1.3 and $4.5 \mathrm{~g}$ per $100 \mathrm{~g}$, respectively (Gil, 2010). However, fruits with high antioxidant capacity such as cranberry, blackberry and raspberry present between 9.6 
and $14.5 \mathrm{~g}$ per $100 \mathrm{~g}$, values higher than those presented by boldo fruit (Zhao, 2007).

The lipid portion of the fruit is usually very low, on the order of $0.1-0.5 \%$ of fresh weight. Only dried fruit (i.e., seeds) contains significant amounts of lipid (Gil, 2010). The boldo fruits presented 3.65 $\mathrm{g}$ lipid per $100 \mathrm{~g}$ (Figure 2). This value is higher than those reported for fruits such as myrtle and maqui, containing 0.3 and $0.8 \mathrm{~g}$ of fat per $100 \mathrm{~g}$, respectively (Tacón, 2004), or compared to the lipid content of sweet cherry (Prunus avium) cv.

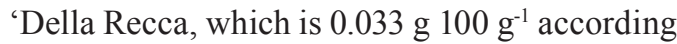
Pacifico et al. (2014). However, this value is lower than those of fruits that are characterized by their high fat content such as the avocado, which has $13.8 \mathrm{~g}$ of fat $100 \mathrm{~g}^{-1}$ of sample (Gil, 2010), or green olives, which can vary from 17.7 to 43.5 g per 100 g (Tanilgan et al., 2007).

Regarding protein content, the boldo fruits presented $0.78 \mathrm{~g}$ of protein per $100 \mathrm{~g}$ (Figure 2). This value is similar to those reported for other fruits such as maqui and cranberry, which contain $0.8 \mathrm{~g} 100$

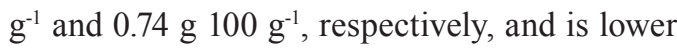
compared to blackberry and raspberry, which

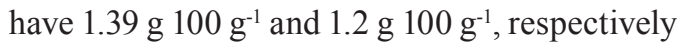
(Tacón, 2004; Zhao, 2007). The protein content of fruit is low, usually not more than $1 \%$, and most of this protein fraction consists of enzymes involved in the maturation process (Gil, 2010). Only fruits such as açaí (Euterpe oleraceae) have

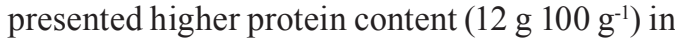
the mature state.

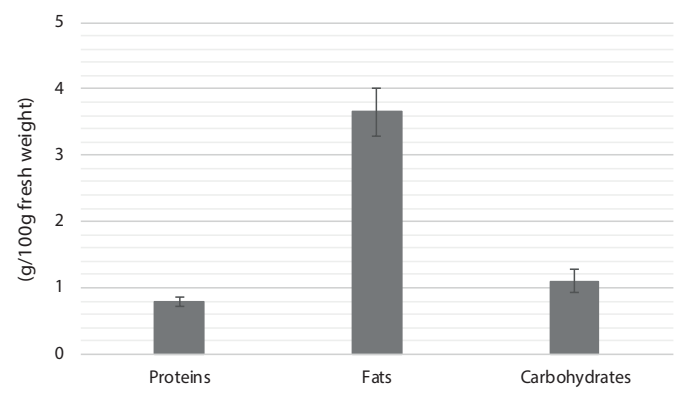

Figure 2. Total content of proteins, fats and carbohydrates at stage III (mean $\pm \mathrm{SD} ; \mathrm{n}=3$ )

\section{Total phenolic content}

Phenols have very different functions in plants. Many have roles in plant defense against herbivores or pathogens; others are involved in the mechanical support for attracting pollination and dispersing fruit, in absorbing harmful ultraviolet radiation or reducing the growth of adjacent competing plants (Taiz and Zeiger, 2006).

Total phenols by the FC method increased between states I and II and then decreased in state III (Figure 3). The highest value was reached in state II, with EAG $472 \mathrm{mg} \mathrm{kg} \mathrm{FW}{ }^{-1}$. This value is lower than the total phenol content reported for other fruits such as raspberry and cranberry (5040 $\mathrm{mg} \mathrm{EAG} \mathrm{kg} \mathrm{FW}^{-1} 7090 \mathrm{mg} \mathrm{EAG} \mathrm{kg} \mathrm{FW}^{-1}$ ) and similar to that of fruits such as melon and watermelon (590 mg EAG kg FW"-1, EAG $720 \mathrm{mg}$ $\left.\mathrm{kg} \mathrm{FW}^{-1}\right)(\mathrm{Wu}$ et al., 2004).

Similar behavior has been reported in other fruits. According Mikulic-Petkovsek et al. (2014), the red gooseberry cultivar 'Junifer' from the genus Ribes has increased content of total phenols in state II and a decrease in state III, corresponding to the final state of maturity. Similar behavior is observed in the fruit camu (Myrciaria dubia) (Chirinos et al., 2010).

The total phenolic content is closely related to levels of individual phenols, and an increase in certain types of compounds can yield a high content of total phenols in plant tissues. The progressive

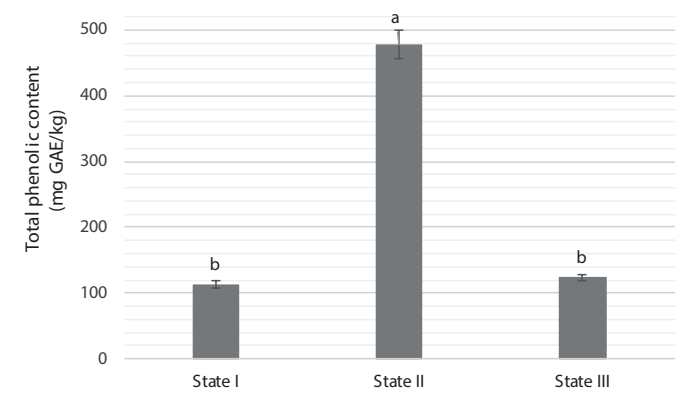

Figure 3. Total phenolic content of Peumus boldus fruit. (Mean $\pm \mathrm{SD} ; \mathrm{n}=3$ ). Different letters imply significant differences $(\mathrm{p}<0.05)$. 


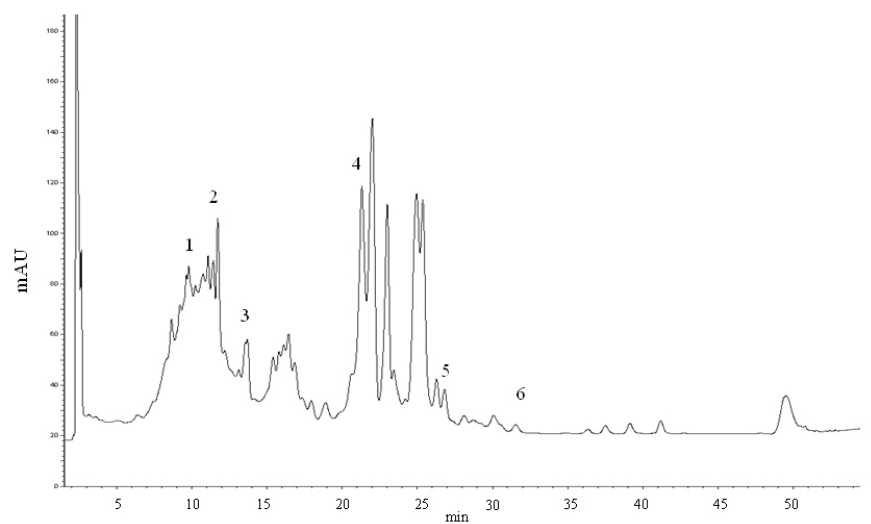

Figure 4. HPLC-DAD chromatogram of Peumus boldus fruit in stage III. Peak 1. catechin, 2. epicatechin, 3. p-coumaric acid, 4. rutin, 5. abscisic acid, and 6. quercetin. (Mean $\pm \mathrm{SD} ; \mathrm{n}=3$ )

increase in total phenols during development may be due to high levels of anthocyanins, hydroxycinnamic acid, ellagic acid, flavonols and flavones (Mikulic-Petkovsek et al., 2014).

To better characterize the phenolic content in boldo fruit, an analysis of the chromatographic profile of different polyphenols was performed by liquid chromatography. The chemical profile obtained with HPLC-DAD is presented in Figure 4, where signals from catechin, epicatechin, $p$ coumaric acid, rutin, abscisic acid and quercetin can be identified by comparing the retention times of available phenolic acid and flavonoid standards. However, peaks from other unidentified polyphenols are observed.

The identification was confirmed by HPLCMS/MS, and calibration curves were used to determine the concentrations of the polyphenols. Epicatechin presented the highest concentration $\left(2.94 \pm 0.65 \mathrm{mg} 100 \mathrm{~g}^{-1}\right.$ fruit) followed by catechin $\left(2.71 \pm 0.80 \mathrm{mg} 100 \mathrm{~g}^{-1}\right.$ fruit), while lower concentration was observed for abscisic acid. When compared with the FC phenolic content these values are significantly lower; however, compounds such as anthocyanidin and non-phenolic compounds such as reductive sugars (fructose, glucose, and sucrose) and organic acids (ascorbic, citric and tartaric acids) are capable of interfering with the assessment of phenolics by FC assay.

The main conclusions are as follows. According to the results obtained in this research, the fruits of Peumus boldus can grow alone or in a group because they originate from an apocarpous ovary. In this research, it was more common to find single fruits than grouped fruits.

The ash content, crude fiber, total protein and total sugars in the boldo fruit were similar to those of other fruits. Special attention can be paid to the fat content presented by boldo fruit, which is higher than that of most fleshy fruits, and the possibility of using them in the production of essential oil should be investigated. Total phenolic content values were lower than those from antioxidant fruits, but the high content of catechin and epicatechin could be of interest due to their pharmacological activities.

\section{Acknowledgements}

To projects FIC Regional IDI 30126395-0 Desarrollo de Biozonas Apícolas and Interdisciplinario VRI-UC N ${ }^{\circ} 13 / 2013$; to CONICYT Beca Doctorado Nacional y Gastos Operacionales No 21110822; The authors declare that there is no conflict of interest regarding the publication of this paper. 


\section{Resumen}

P. Velásquez, M.I. Sandoval, A. Giordano, M. Gómez, y G. Montenegro. 2017. Composicñión Nutricional y Contenido de Polifenols de las frutas comestibles de Peumus boldus Mol. Cien. Inv. Agr. 44(1): 64-74. Peumus boldus es un árbol endémico de Chile cuyos frutos comestibles no han sido investigados científicamente. El objetivo de este estudio fue determinar su composición nutricional (humedad, cenizas, fibra cruda, proteínas, carbohidratos y lípidos) y su contenido polifenólico (contenido de fenoles totales, análisis HPLC-DAD, HPLC-MS / MS) en diferentes etapas de desarrollo. Los resultados mostraron que los frutos disminuyeron en cenizas, fibra cruda y el contenido fenólico total a lo largo de su desarrollo; mientras que su contenido de carbohidratos y proteínas aumentó. También se observó un incremento en algunos flavonoides tales como catequina y epicatequina. Este es el primer informe de la composición nutricional y contenido fenólico de los frutos de Peumus boldus Mol.

Palabras clave: Cenizas, contenido de fenoles totales, fibra cruda, Goldfish, Kjeldahl, método de fenol-sulfúrico.

\section{References}

Acosta-Montoya, O., F. Vaillant, S. Cozzano, C. Mertz, A. M. Pérez, and M. Castro. 2010. Phenolic content and antioxidant capacity of tropical Highland blackberry (Rubus adenotrichus Schltdl.) during three edible maturity stages. Food Chem 119:1497-1501.

AOAC. 2001. Official Method of Analysis. 17th ed. Association of Official Analytical Chemists.

Arena, M., and N. Curvetto. 2008. Berberis buxifolia fruiting: Kinetic growth behavior and evolution of chemical properties during the fruiting period and different growing seasons. Sci. Hortic. 118 (2):120-127.

Beretta, G., P. Granata, M. Ferrero, M. Orioli, R. Facino. 1996. Standardization of antioxidant properties of honey by a combination of spectrophotometric/fluorimetric assays and chemometrics. Anal. Chim. Acta. 553(2):185-191.

Bittner, M., M.A. Aguilera, V. Hernández, C. Arbert, J. Becerra, and M.E. Casanueva. 2009. Fungistatic activity of essential oils extracted from Peumus boldus Mol., Laureliopsis philippiana (Looser) Schodde and Laurelia sempervirens (Ruis \& Pav.) Tul. (Chilean Monimiaceae). Chil J Agr Res 69(1):30-37.
Botti, C., and A. Cabello. 1990. Anatomía y desarrollo de flores, frutos y semillas de boldo (Peumus boldus Mol.). Ciencia e Investigación Forestal 4(1):49-60.

Cai, C., C. Xu, X. Li, I. Ferguson, and K. Chen. 2006. Accumulation of lignin in relation to change in activities of lignification enzymes in loquat fruit flesh after harvest. Postharvest Biol. Technol. 40(2):163-169.

Chirinos, R., J. Galarza, I. Betalleluz-Pallardel, R. Pedreschi, and D. Campos. 2010. Antioxidant compounds and antioxidant capacity of Peruvian camu camu (Myrciaria dubia (H.B.K) McVaugh) fruit at different maturity stages. Food Chem 120:1019-1024.

Coombe, B.G. 1976. The development of fleshy fruits. Annu Rev Plant Physiol 27:507-528.

Dubois, M., K.A. Gilles, J.K. Hamilton, P.A. Rebers, and F. Smith. 1956. Colorimetric method for determination of sugars and related substances. Anal. Chem. 28(3):350-356.

Ertl. P, and A. Schuffenhauer. 2008. Cheminformatics analysis of natural products: lessons from nature inspiring the design of new drugs. Prog Drug Res 66:217-235.

Estrada, B., M. Bernal, J. Díaz, F. Pomar, and F. Merino. 2000 Fruit Development in Capsicum 
annum: Changes in Capsaicin, Lignin, Free Phenolics, and Peroxidase Patterns. J. Agric. Food Chem. 48(12):6234-6239.

Fredes, C. 2009. Antioxidantes en berries nativos chilenos. Boletín Latinoamericano y del Caribe de Plantas Medicinales y Aromáticas 8(6):469-478.

Gil-Albert Velarde, F. 2006. Tratado de arboricultura frutal. Morfología y fisiología del árbol frutal, vol. 1. Editorial Mundi Prensa, España.

Gordon, A., A. P. Gil, L. Corrêa, S. Cordeiro de Freitas, C. M. Araujo, C. Marino, R. de Andrade, M. Friederich, V. Martins, and F. Marx. 2012. Chemical characterization and evaluation of antioxidant properties of Açaí fruits (Euterpe oleraceae Mart.) during ripening. Food Chem 133:256-263.

Gil Hernández, A. 2010. Tratado de Nutrición: Composición y Calidad Nutritiva de los Alimentos, Volumen 2. Editorial Médica Panamericana.

Khoddami, A., M. Wilkes, and T. Roberts. 2013. Techniques for Analysis of Plant Phenolic Compounds. Molecules 18(2):2328-2375.

Kirk, R. S., R. Sawyer, and H., Egan. 1996. Composición y análisis de alimentos de Pearson, segunda edición. Compañía editorial continental SA de CV, México.

Kramer, P.J., and T. Kozlowski. 1976. Physiology of Woody Plants. Academic Press, New York.

Krause, J., and G. Tobin. 2013. Discovery, development and regulation of natural products, using old solutions to new problems - Natural drug discovery in the $21^{\text {st }}$ century, Dr. Marianna Kulka (Ed.), InTech.

Mikulic-Petkovsek, M., J. Rescic, V. Schmitzer, F. Stampar, A. Slatnar, D. Koron, and R. Vaberic. 2014. Changes in fruit quality parameters of four Ribes species during ripening. Food Chem 173:363-374.

Montenegro, G. 2002. Chile nuestra flora útil. Colección de Agricultura. Facultad de Agronomía e Ingeniería Forestal. Pontificia Universidad Católica de Chile.

Nielsen, S. 2003. Food analysis, 3rd edition. Kluwer Academic/Plenum Publishers, USA.

Pacifico, S., A. Di Maro, M. Petriccione, S. Galasso, S. Piccolella, A. Di Giuseppe, M. Scortichini, and P. Monaco. 2014. Chemical composition, nutritional value and antioxidant properties of autochthonous Prunus avium cultivars from Campania Region. Food Res. Int. 64:188-199.

Pomeranz Y., and C.W. Meloan. 2000. Food Analysis Theory and Practice, 3rd edition. Chapman \& Hall, USA.

Rodríguez, R., A. Jiménez, J. Fernández-Bolaños, R. Guillén, and A. Heredia. 2006. Dietary fibre from vegetable products as source of functional ingredients. Trends Food Sci Technol 17:3-15.

Rodríguez, R., O. Matthei, and M. Quezada. 1983. Flora arbórea de Chile. Editorial de la Universidad de Concepción, pp. 265.

Romanov, M., P.K. Endress, A. V. F. CH. Borrov, A.P. Melikian, and A. Palmarola. 2007. Fruit structure and systematics of Monimiaceae s.s (Laurales). Bot J Linn Soc 153:265-285.

Schmidt Hebbel, H., I. Pennacchiotti, S. Avendaño, L. Masson, E. Witting, and E. Amadori. 2001. Avances en Ciencia y Tecnología de los Alimentos. Facultad de Ciencias Químicas y Farmacéuticas. Universidad de Chile.

Tacón, A. 2004. Manual de productos forestales no madereros. Programa de Fomento para la Conservación de Tierras Privadas de la Décima Región. Centro de Investigación y Planificación para el Medio Ambiente (CIPMA).

Taiz, L., and E. Zeiger. 2006. Fisiología vegetal. Universitat Jaume I. España.

Tanilgan, K., M. Özcan, A. Ünver. 2007. Physical and chemical characteristics of five Turkish olive (Olea europea L.) varieties and their oils. Grasas y Aceites 58(2):142-147.

Valvi, S.R., and V.S. Rathod. 2011. Mineral composition of some wild edible fruits from Kolhapur district. International Journal of applied biology and Pharmaceutical technology 2(1):392-396.

Wu, X., G. Beecher, J. Holden, D. Haytowitz, S. Gebhardt, and R. Prior. 2004. Liophilic and Hydrophilic Antioxidant Capacities of Common Foods in the United States. J. Agric. Food Chem. 52(12):4026-4037.

Zhao, Yanyun. 2007. Berry Fruit: Value-Added Products for Health Promotion. Ed. CRC Press. U.S.A. 